\title{
KONSEP POLIGAMI DALAM ALQURAN: STUDI TAFSIR AL-MIȘBĀḤ KARYA M. QURAISH SHIHAB
}

Siti Asiyah ${ }^{1}$, Muhammad Irsad ${ }^{2}$, Eka Prasetiawati ${ }^{3}$, Ikhwanudin ${ }^{4}$

${ }_{1,2,3,4}$ Institut Agama Islam Ma'arif NU (IAIMNU) Metro Lampung

*CORRESPONDENCE: $\triangle$ aisasiyah68@gmail.com

\begin{abstract}
This paper aims to understand the interpretation of the polygamy verse from the perspective of contemporary Indonesian interpreters represented by M.Quraish Shihab as a problem solving for the rampant practice of polygamy in society. The discourse of polygamy in Islamic thought is an interesting controversy discussed. As offered by M. Quraish Shihab in his interpretation that polygamy in Islamic teachings is permissible not as a recommendation or as a mandatory thing, even then on fair terms. The existence of differences in each argument has the same basis of the Qur'anic text, namely Surat an-Nisa 'verse 3. The practice of polygamy sometimes has an impact on family relations that are not harmonious and unfair, on this basis polygamy needs to be reviewed with other approaches. To limit the study in this paper, this research uses a qualitative approach by applying a thematic interpretation method to obtain a comprehensive understanding of polygamy in the Qur'an. Polygamy in al-Misbah's interpretation is said to be fair, just here is not only immaterial (love and affection) but justice in measured material is not only obeying lust.
\end{abstract}

Abstrak
Tulisan ini bertujuan memahami tafsir ayat poligami perspektif mufassir
Indonesia kontemporer yang diwakili oleh M.Quraish Shihab sebagai problem
solving atas maraknya praktek poligami di masyarakat. Wacana poligami
dalam pemikiran Islam menjadi kontroversi yang menarik dibahas.
Sebagaimana ditawarkan M. Quraish Shihab dalam tafsirnya bahwasanya
poligami dalam ajaran Islam diperbolehkan bukan bersifat anjuran atau hal
yang wajib, itupun dengan syarat adil. Adanya perbedaan setiap argumen
mempunyai dasar yang sama dari teks al-Qur'an yaitu surat an-Nisa' ayat 3 .
Praktik poligami terkadang berdampak pada hubungan keluarga yang tidak
harmonis dan kurang adil, atas dasar ini poligami perlu dikaji ulang dengan
pendekatan-pendekatan lain. Untuk membatasi kajian dalam tulisan ini maka,
Penelitan ini menggunaan pendekatan kualitatif dengan menerapkan metode
tafsir tematik (maudū'i) untuk memperoleh pemahaman yang komprehensif
tentang poligami dalam al-Qur'an. Poligami dalam tafsir al-Misbah dikatakan
boleh dengan syarat adil, adil di sini bukan hanya bersifat immaterial (cinta dan
kasih sayang) melainkan keadilan pada materi yang terukur bukan hanya
menuruti hawa nafsu.

\section{A. Pendahuluan}

Melihat awal sejarah munculnya poligami memang sudah berumur ratusan tahun bahkan ribuan tahun lalu pada masa jahiliyah atau masa belum adanya agama Islam. Budaya tersebut sekarang turut berkembang secara modern dan mengikuti perkembangan zaman, dengan kondisi masyarakat saat ini menjadi kurva naik turunnya perbandingan pernikahan poligami dengan semakin majunya zaman, dimana problematika dalam rumah tangga semakin meninggi dengan adanya isu-isu "pelakor" yang semakin viral di media sosial. 
Dilihat dari aspek hukum, poligami hanyalah tindakan hukum dalam kategori ibăhah (boleh), bukan sunnah terutama wajib. Secara relevan Meskipun banyak buku telah ditulis oleh para ahli, setiap pendapat yang diungkapkan selalu mencerminkan tren tertentu, serta gambar emosional yang bervariasi dari satu penulis ke penulis lainnya. ${ }^{1}$

Polemik tentang poligami semakin mengemuka dan menarik perhatian ketika praktik poligami secara terang-terangan dilakukan oleh para publik figur mulai dari pengusaha, politisi, ulama, sampai pelawak. Poligami kemudian menjadi subjek diskusi dan perdebatan yang mewarnai wacana publik kami. Banyaknya timbul masalah poligami selalu menarik perhatian, bagi kaum perempuan yang tidak menyukai poligami dan menganggapnya sebagai sesuatu yang membahayakan kedudukan dan peran sebagai seorang istri berbeda bagi kaum laki-laki yang sebagian besar menjadikan poligami sebagai bagian darinya. ${ }^{2}$ Terdapat pasal undang-undang nasional yang tidak relevan dan jauh dari kemaslahatan masyarakat Indonesia, khususnya jauh dari nilai-nilai keadilan kaum perempuan. Impikasi yang ditimbulkan bermacam-macam, diantaranya perempuan mengalami ragam ketidakadilan, marginalisasi, subordinasi, stereotip dan lain-lain. Dengan kondisi rill seperti itu wajar apabila kemudian status peran perempuan dinilai lebih buruk, khususnya ketidakadilan dalam bidang perkawinan. ${ }^{3}$

Dalam diskursus hukum Islam, persoalan poligami adalah satu wacana yang selalu menarik untuk diperbincangkan dan diperdebatkan. Dan perdebatan tentang masalah poligami ini selalu berujung pada ketidak sepakatan, yang sering kali menimbulkan perseteruan antara orang-orang yang pro dan kontra. Dengan beberapa alasan antara lain: suami menjadi kaya bahkan lebih kaya, istri tidak cantik lagi dan belum hamil, istri sakit menahun, istri mengandung dan melahirkan dan kondisi istri stagnan. Maka dengan faktor-faktor tersebut, naik turunnya kepercayaan diri suami terhadap istri bisa saja menurun dan memunculkan keinginan untuk poligami.

Poligami di Indonesia juga pernah di alami oleh pejuang kita RA. Kartini. Bahkan poligami menjadi topik dalam surat kartini, sedangkan kita tahu surat-surat kartini tersebut ditulis jauh sebelum indonesia merdeka. Perbincangan tentang poligami sepertinya tidak pernah berhenti. Barubaru ini, percakapan telah berubah menjadi perdebatan yang menarik, terutama sejak era Pasca Orde Baru. Poligami “diatur" oleh Pemerintah melalui peraturan pemerintah Republik Indonesia nomor 9 tahun 1975 tentang pelaksanaan undang-undang nomor 1 tahun 1974 tentang perkawinan. Banyak bangsa muslim yang saat ini menganggap poligami tidak konstitusional telah membenarkan perubahan-perubahan dalam perundang-undangan berdasarkan perspektif al-Qur'ān tentang perkawinan, maupun tentang perspektif perkawinan islam modern.

Namun pada realitasnya, praktek poligami sering dilakukan dengan tanpa pertimbanganpertimbangan matang yang mencangkup segala akibat dan dampak yang timbul darinya, bahkan ada beberapa publik figur yang melakukan praktek poligami. ${ }^{4}$ Dan tanpa memperhatikan faktor

\footnotetext{
${ }^{1}$ Agus Sunaryo, "Poligami Di Indonesia (Sebuah Analisis Normatif-Sosiologis)," Yin Yang 5, no. 1 (2010): $143-167$.

${ }^{2}$ Rochayah Machali, Wacana Poligami Di Indonesia (Bandung: Mizan, 2005).

${ }^{3}$ Dina Agnia, "KAJIAN KRITIS BUDAYA PATRIARKHISME DALAM AGAMA DAN KEADILAN PEREMPUAN (STUDI KETENTUAN POLIGAMI DALAM UU. NO. 1 TAHUN 1974)," FIKRI: Jurnal Kajian Agama, Sosial dan Budaya $\quad$ Vol. $1, \quad$ No. $1, \quad$ (Juni 2016), http://journal.iaimnumetrolampung.ac.id/index.php/jf/article/view/283.

${ }^{4}$ Imam machaly, "Poligami dalam Perdebatan teks dan konteks: melacak jejak argumentasi poligami dalam teks suci” 08, Nomor 01 (2016).
} 
keadilan dan konsekuwensinya sebagaimana diatur dalam al-Qur'an dan al-sunnah sehingga mewarnai wacana publik.

Dalam Islam memperbolehkan seorang pria Muslim menikahi empat wanita sekaligus (poligini) jika dia mampu mempertahankan dan menerapkan keadilan kepada istri-istrinya tentang hidup, hidup dan berbagi waktu. Jika, khawatir tidak bisa melakukan keadilan (poligami) maka dilarang menikahi lebih dari satu wanita, sama seperti dilarang menikahi lebih dari empat orang. ${ }^{5}$ Karena takutnya berlaku aniaya. Dalam surat an-Nisā', ayat 3 yang berbunyi:

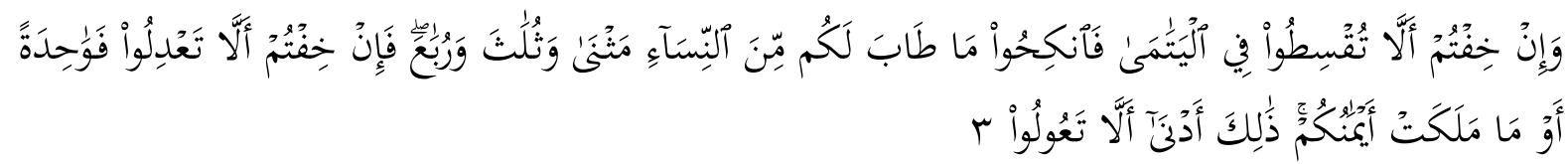

Dan jika kamu takut tidak dapat berlaku adil terhadap (hak-hak) perempuan yang yatim (jika kamu menikahinya), Maka nikahilah wanita-wanita (lain) yang kamu senangi : dua, tiga atau empat. kemudian jika kamu takut tidak akan bisa berlaku adil, Maka (nikahilah) seorang saja, atau budakbudak yang kamu miliki. Yang demikian itu adalah lebih dekat kepada tidak berbuat aniaya. ${ }^{6}$

M. Quraish Shihab menegaskan bahwa adil yang dimaksud ayat tersebut yakni adil yang tidak dapat diwujudkan dalam hati secara terus-menerus, maksudnya adil dalam hal cinta antara para istri-istri, walaupun sangat ingin melakukan itu, karena cinta merupakan melampaui kemampuan manusia untuk mengaturnya. yaitu dalam hal-hal yang material, keadilan yang tidak dapat diwujudkan itu adalah dalam hal cinta. ${ }^{7}$ Keluarga adalah jiwa dan tulang punggung suatu negara, kesejahteraan lahir batin yang dialami adalah cerminan dari situasi keluarga yang hidup di tengahtengah masyarakat itu sendiri. Dengan demikian, jika kita menginginkan tercipta negara baldatun thayyibatun, landasan yang harus kita bangun adalah masyarakat marhamah yaitu terciptanya keluarga sakinah. Adapun pilar yang harus ditegakkan untuk mewujudkannya adalah akidah, mawaddah dan rahmah.

Di zaman modern seperti sekarang banyak perempuan yang menolak jika menjadi istri kedua. Dalam sejarah manusia, perkembangan poligami akan slalu mengikuti cara orang memandang wanita. Jika derajat dan kedudukan masyarakat perempuan tidak sejajar, maka banyak yang beranggapan bahwa praktik poligami akan berkembang subur. Berbeda jika perspektif masyarakat tentang perempuan sebagai mitra sejajar, maka poligami hanyalah sebuah kasus yang berkembang di tengah masyarakat dengan dijadikannya sebuah "budaya". Cara pandang masyarakat yang perlu ditegaskan terkait gender karena kurangnya pemahaman mereka dalam masalah poligami.

Dampak yang umum terjadi pada istri atau wanita yang suaminya menikah lagi (berpoligami), umumnya timbul perasaan rendah diri pada sang istri, menyalahkan diri sendiri, dan merasa tindakan suaminya berpoligami adalah karena ketidakmampuannya untuk memenuhi kebutuhan biologis suaminya. Dengan adanya dampak negatif yang terjadi, atas dasar itu poligami slalu menjadi masalah dan berdebatan panjang yang tiada akhirnya, tanpa adanya pemahaman yang sama antara suami dan istri. Orang tua adalah orang yang memegang peranan penting dalam keluarga.[8] Disini penulis ingin membahas tentang beberapa konsep dalam poligami agar kiranya ada keterpaduan satu sama lain diantara suami dan isteri. Setelah meneliti banyak orang yang melakukan poligami di Indonesia yaitu orang-orang yang memiliki pemahaman agama lebih,

\footnotetext{
${ }^{5}$ H.S.A Al Hamdani, Risalah Nikah (Hukum Perkawinan Islam) (Jakarta: Pustaka Amani, 2002).

${ }^{6}$ Al-Qur'an [4]: 3.

${ }^{7}$ M. Quraish Shihab, Tafsir al-misbah, pesan, kesan dan keserasian al qur'an, vol. 2 (Tanggerang: Lentera
} Hati, 2006). 
dimana mereka beranggapan bahwasannya tujuan poligami bagi mereka untuk memperbaiki keturunan dan menghindari terjadinnya perzinaan yang merajalela.

Poligami merupakan sebuah fenomena yang menarik perhatian publik di semua kalangan sehingga menjadi sebuah fenomena yang kontroversial disegala penjuru dunia terutama di NegaraNegara Muslim, sehingga penuh dengan perdebatan. Poligami merupakan fakta sejarah dan budaya kaum terdahulu, itu semua dipaparkan dalam al-Qur'an dan hadits, namun bagaimana publik mengeksplorasi makna tersebut. Dalam penelitian ilmiah, satu hal penting yang mesti dilakukan peneliti adalah merekontruksi masa lampau secara sistematis dan objektif, yaitu dengan cara mengumpulkan, mengevaluasi, dan memverifikasikan, serta mensistensiskan bukti-bukti untuk menegakkan fakta dan memeperoleh kesimpulan yang kuat, dihubungkan dengan fakta yang ada pada masa sekarang dan proyeksi masa depan. Hal ini dikenal dengan istilah historical research. ${ }^{\mathbf{8}}$

Sejauh penulusuran penulis, penelitian tentang poligami sudah banyak yang membahas di antaranya, pertama Konsep Muhammad Syahrur Tentang Poligami (Studi Analisis dari Segi Normatif dan Filosofi) oleh Ita Musarrofa yang membahas beberapa konsep poligami menurut Muhammad Syahrur. ${ }^{9}$ Titik perbedaan dalam penelitian ini dengan penelitian yang akan dilakukan terletak pada fokus kajian. Penelitian Ita Musarrofa ini berfokus pada konsep poligami menurut Muhammad Syahrur, sedangkan penelitian ini akan fokus membahas analisis ayat-ayat poligami dalam tafsir al-Miṣbăh. Kedua, Konsep Poligami dalam Islam (Studi Atas Pemikiran Sayyid Qutb) oleh Hikmatulloh yang mendeskripsikan konsep poligami dalam Islam menurut Pandangan Muhammad Sayyid Qutb. ${ }^{10}$ Titik perbedaan penelitian ini dengan penelitian yang akan dilakukan adalah terletak pada fokus kajian. Penelitian sebelumnya fokus pada Pandangan Sayyid Qutb tentang poligami, sedangkan penelitian ini akan fokus membahas analisis ayat-ayat poligami dalam tafsir al-Miṣbăh. Ketiga, Respon Ulama Terhadap Prosedur Izin Poligami Ke Pengadilan: Studi Pandangan Kiai Pesantren Di Kabupaten Bantul oleh Heri Mahfudhi mengkaji tentang respon ulama terhadap prosedur izin poligami ke pengadilan, sedangkan penelitian ini fokusnya membahas analisis ayat-ayat konsep poligami dalam tafsir al-Miṣbāh. Alasan penulis memilih alMisbah sebab tafsir ini karya ulama nusantara yang tentunya faktor kultur dan sosial cocok dan sesuai dengan budaya orang Indonesia. Selain itu, corak tafsir yang digunakan adabi ijtima'i (sosial-masyarakat) tentunya bisa memecahkan isu-isu kontemporer termasuk permasalahan poligami di masyarakat. Tafsir klasik mungkin banyak yang penjelasannya detail dan gamblang dan tidak diragukan lagi kredibilitas tafsirannya, namun penulis tidak menggunakannya sebab penulis lebih cenderung pada mufassir lokal untuk melihat kaitan budaya lokal dengan hasil tafsiran beliau muncul atau tidak.

Isu tentang poligami menjadi isu yang krusial dalam era revolusi industri 4.0 sekarang dimana diperlukan kesetaraan gender dalam memajukan perekonomian, politik dan pendidikan bangsa Indonesia yang memposisikan laki-laki dan perempuan sama yakni memberikan ketegasan bahwa prestasi individual baik dalam bidang spiritual maupun urusan karir profesional, tidak mesti dimonopoli oleh salah satu jenis kelamin saja. Laki-laki dan perempuan memperoleh kesempatan yang sama untuk memperoleh prestasi yang optimal. Masalah yang akan dibahas dalam penelitian

\footnotetext{
${ }^{8}$ Cholid Narbuko Dan Abu Ahmadi, Metodologi Penelitian (Jakarta: Bumi Perkasa, 2009).

${ }^{9}$ Sugiyono, Metode Penelitian Pendidikan; Pendekatan Kuantitatif, Kualitatif dan R\&D (Bandung: Alfabeta, 2013).

${ }^{10}$ Hikmatulloh, "Konsep Poligami Dalam Islam (Studi Atas Penafsiran Sayyid Qutb), (Dalam Skripsi)" 
ini adalah Bagaimana penafsiran dan Analisis ayat-ayat poligami menurut M. Quraish Shihab dalam tafsir Al-Mişbah.

\section{B. Metode Penelitian}

Penelitian ini adalah penelitian kualitatif yang bertujuan mendekripsikan bentuk pemikiran Muhammad Quraish Shihab tentang poligami. Oleh karena itu, penelitian ini dilakukan melalui kajian kepustakaan (library research). Artinya, mengacu pada data-data atau bahan-bahan tertulis yang berkaitan dengan topik pembahasan yang sedang diangkat atau objek utamanya yaitu bukubuku karangan M. Quraish Shihab ${ }^{11}$, sebagai sumber primer adalah Tafsìr al-Miṣbāh pesan, kesan, dan keserasian al-Qur'an. Pendekatan dalam penelitian ini adalah metode maudū'i menurut AlFarmawì yaitu dengan menghimpun ayat-ayat al-Qur'ān yang mempunyai maksud yang sama atau membicarakan topik persoalan yang sama, setelah itu, ayat-ayat tersebut lalu disusun berdasarkan kronologi serta sebab turunnya ayat. Kemudian penafsir memberikan keterangan dan penjelasan serta mengambil kesimpulan. ${ }^{\mathbf{1 2}}$ Dalam penelitian konsep, penulis mencoba menelusuri secara mendalam mengenai konten dalam penafsiran tokoh dalam kitab tafsir dalam hal ini yaitu analisis konsep poligami dalam al-Qur'ān studi tafsir al-Miṣbāh karya M. Quraish Shihab.

Al-Farmawi mengemukakan secara rinci langkah-langkah yang hendaknya ditempuh untuk menerapkan metode maựù'i. Adapun langkah-langkah tersebut adalah: a) Menentukan tema masalah yang akan dibahas, b) Menghimpun ayat-ayat yang berkaitan dengan tema tersebut, c) Menyusun sekuensial ayat sesuai dengan kronologis turunnya, disertai pengetahuan tentang asbāb al-nuzūl, d) Memahami munasabah (korelasi) ayat-ayat tersebut dalam surahnya masing-masing, e) Menyusun kerangka pembahasan yang sempurna (outline), f) Melengkapi pembahasan dengan hadist-hadist yang relevan, g) Meneliti ayat-ayat tersebut secara keseluruhan dengan cara menghimpun ayat yang mempunyai pengertian sama, atau mengompromikan antara yang 'àm (umum) dan yang khas (khusus), mutlak dan muqayyad (terikat). ${ }^{\mathbf{1 3}}$

Peneliti telah menemukan beberapa teknik pengumpulan data, dimana peneliti mengunakan dalam teknik dokumentasi. Dokumentasi adalah teknik pengumpulan data yang ditunjukan kepada subyek penelitian yang dimaksud disini adalah metode pengumpulan data yang dilakukan dengan cara mencari dokumen berupa catatan pribadi, surat pribadi, buku harian, laporan kerja, notulen rapat, catatan khusus, rekaman kaset, rekaman video, foto dan lain sebagainnya. ${ }^{\mathbf{1 4}}$ Teknik pengumpulan data peneliti menggunakan dokumentasi, yakni metode pengumpulan data yang dilakukan dengan cara mencari dokumen berupa catatan pribadi, surat pribadi, buku harian, laporan kerja, notulen rapat, catatan khusus, rekaman kaset, rekaman video, foto dan lain sebagainya.

Metode analisis data memakai content analysis yakni kandungan isi yang tidak akan lepas dari interpretasi sebuah karya. Secara metodologis, Analisis isi dimaksudkan melakukan analisis terhadap makna yang terkandung dalam masalah yang hendak dibahas, biasanya digunakan dalam penelitian yang bersifat normatif. Pada dasarnya analisis data melalui tahapan, kategorisasi dan klasifikasi, perbandingan, dan pencarian hubungan antara data yang spesifik tentang hubungan antar pengubah. ${ }^{15}$

\footnotetext{
${ }^{11}$ Sukandarrumidi, Metodologi Penelitian (Yogyakarta: Gajah Mada University Press, 2004).

${ }^{12}$ Makrum Makrum, "POLIGAMI DALAM PERSPEKTIF AL-QUR'AN," MAGHZA 1, no. 2 (2016): 41-56.

${ }^{13}$ Didi Junaedi, "Mengenal Lebih Dekat Metode Maudhu'i” 04 Nomor 01 (Juni 2016).

${ }^{14}$ Sukandarrumidi, Metodologi Penelitian.

${ }^{15}$ Rosihan Anwar, Ilmu Tafsir (Bandung: CV Pustaka Setia, 2008).
} 


\section{Pembahasan}

\section{Penafsiran Ayat-Ayat Poligami Menurut M. Quraish Shihāb dalam Tafsīr Al-Miṣsbāh}

M. Quraish Shihab berasal dari keluarga ulama yang berpengaruh di Makassar. Ayahnya, Abdurrahman Shihab adalah seorang guru besar dalam bidang tafsir. Quraish Shihab lahir di Rappang, Sulawesi Selatan, 16 Februari 1944. Tamat dari SMP beliau mondok ke Malang di Pesantren Darul Haditsal-Fiqhiyyah. Kemudian beliau melanjutkan pendidikan S1-S2 ke Mesir jurusan Tafsir Hadits Universitas Al-Azhar mengambil spesialisasi bidang tafsir Alquran dengan predikat cumlaude. Beliau adalah satu-satunya orang yang meraih gelar doktor di al-Azhar dengan predikat itu. Sepulang dari Mesir beliau dipercaya menduduki jabatan penting dan strategis di Pascasarjana Uin Jakarta sebagai rektor, ketua MUI, lajnah Pentashih Alquran, ICMI dll. Akhirnya beliau mengarang tafsir al-Misbah 30 juz sebanyak 15 jilid selama kurun waktu 30 tahun. Berkat tafsirnya beliau dikenal sebagai pakar tafsir paling terkemuka di Indonesia, bahkan untuk tingkat Asia Tenggara. Beliau termasuk mufassir kontemporer yang sangat produktif dalam berkarya sebagaimana karya dan publikasinya yang bisa dibaca sekarang ini. Al-Misbah populer dengan aksen ungkapan balagah dan i'jaz alquran yang kental serta penjelasan kandungan alquran yang kaya yaitu munasabah, makki madani, hukum alam, tatanan masyarakat, umat dsb.

Bagi kalangan yang mendukung adanya poligami akan mendasarkan argumen mereka kepada Firman Allah Swt pada QS. Al-Nisẳ: 3 berbunyi: ${ }^{16}$

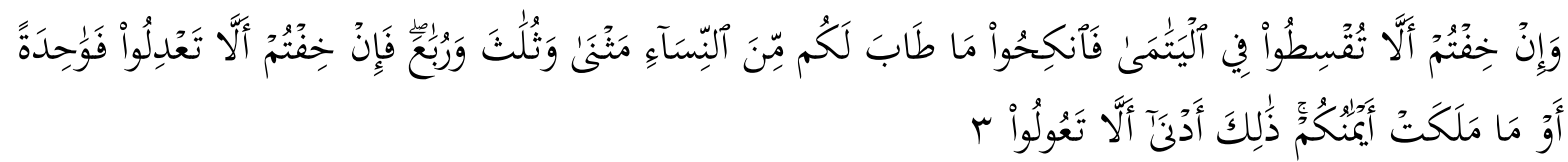

Setelah melarang mengambil dan memanfaatkan harta anak yatim secara aniaya, kini yang dilarang adalah berlaku aniaya terhadap pribadi anak-anak yatim itu. Karena itu, ditegaskannya bahwa "jika kamu takut tidak dapat berlaku adil terhadap perempuan yatim dan kamu percaya diri akan berlaku adil terhadap wanita selain yatim, maka nikahilah apa yang kamu senangi sesuai selera kamu dan halal dari wanita yang lain". Jika perlu, kamu bisa menggabungkan dua, tiga atau empat tetapi jangan lebih, "lalu jika kamu takut tidak dapat berlaku adil" dalam hal harta dan perlakuan lahiriah, bukan dalam hal cinta bila menikah lebih dari satu, maka nikahilah seorang saja atau hamba sahaya-mu yaitu menikahi selain anak yatim yang mengakibatkan ketidakadilan, dan mncukupkan satu istri adalah lebih dekat kepada tidak berbuat aniaya, yakni lebih mengantarkan kepada keadilan, atau tidak memiliki banyak anak yang harus kamu tanggung biaya hidup mereka.

Ayat di atas menggunakan kata تعسطوا) dan (تعدلوا) yang keduanya diterjemahkan adil. Ada ulama yang menyamakan makna ta'dilü dan tuqsitu sebagian lain berbeda pendapat bahwasanya berlaku adil antara dua orang atau lebih, keadilan yang menjadikan keduanya senang. Sedang adil adalah berlaku baik terhadap orang lain maupun diri sendiri, tapi keadalian itu, bisa saja tidak menyenangkan salah satu pihak. ${ }^{17}$ Firman-Nya: "maka nikahilah apa yang kamu senangi bukan siapa yang kamu senangi”, menurut Al-Biqā’i apa mengisyaratkan wanita kurang berakal dengan Hati, 2002).

${ }^{16}$ M. Quraish Shihab, Tafsir Al-Misbah Pesan, Kesan, dan Keserasian Al-Qur'an, 02 vol. (Jakarta: Lentera

${ }^{17}$ M. Quraish Shihab, Tafsir Al-Misbah Pesan, Kesan, dan Keserasian Al-Qur'an, hlm. 338. 
alasan pertanyaan yang dimulai dengan apa tertuju untuk sesuatu yang tidak berakal dan siapa bagi yang berakal.

Firman-nya: "ما ملكت أيمانكم)" diterjemahkan dengan hamba sahaya wanita yang kamu miliki, menunjuk kepada satu kelompok masyarakat masa itu merupakan suatu fenomena umum masyarakat manusia di dunia. Dapat dipastikan, Allah dan Rasul-Nya tidak merestui perbudakan, walau pada saat yang sama harus diakui juga bahwa al-Qur'an tidak menghapusnya sekaligus. AlQur'an dan sunnah menutup semua pintu berkembangnya perbudakan kecuali satu pintu yaitu tawanan, akibat peperangan dalam rangka mempertahankan diri dan akidah, karena ketika itu perlakuan manusia terhadap tawanan perangnya sedemikian buruk. Namun walaupun tawanan perang diperbolehkan diperbudak, tapi perlakuan terhadap mereka sangat manusiawi, bahkan alQur'an memberika peluang kepada penguasa muslim untuk membebaskan mereka dengan tebusan atau tanpa tebusan, berbeda dengan sikap umat manusia ketika itu.

Islam menempuh cara bertahap dalam pembebasan budak berdasarkan situasi dan kondisi para budak yang ditemui. Dalam kaidah fiqh yang dirumuskan para ulama terdahulu kita menjumpai kaidah "al- 'àdah muhakamah" (kebiasaan yang baik). ${ }^{\mathbf{1 8}}$ Para budak zaman itu hidup bersama tuan mereka, sehingga kebutuhan sandang, pangan dan papan mereka terpenuhi. Anda dapat membayangkan bagaimana jadinya jika perbudakan dihapus sekaligus. Pasti akan terjadi problema sosial, yang jauh dari PHK (Pemutusan Hubungan Kerja). Ketika itu para budak jika dibebaskan bukan saja pangan yang harus mereka siapkan sendiri, tetapi juga papan. Atas dasar itu, kiranya dapat dimengerti jika al-Qur'an menghapus perbudakan step by step. Dalam konteks ini, dapat dipahami perlunya aturan hukum bagi para budak tersebut. Salah satu tuntunan itu adalah izin menikahi budak wanita. Ini bukan saja karena mereka juga manusia yang mempunyai kebutuhan biologis, tetapi juga cara menghapus perbudakan. Seorang budak perempuan yang dinikahi budak lelaki, maka dia akan tetap menjadi budak dan anaknya pun demikian, tetapi bila dinikahi oleh pria merdeka, dan memperoleh anak, maka anaknya lahir bukan lagi sebagai budak, dan ibu sang pun demikian. Dengan demikian, pernikahan seorang merdeka dengan budak wanita, merupakan salah satu cara menghapus perbudakan. ${ }^{19}$

Di sisi lain, walau perbudakan secara resmi tidak dikenal lagi oleh umat manusia dewasa ini, tetapi bukan berarti hal ini dinilai tidak relevan lagi. Ini karena al-Qur'an tidak hanya diturunkan untuk generasi abad ini, tetapi ia diturunkan untuk umat manusia zaman dahulu, sekarang dan akan datang. Semua di beri petunjuk dan semua menimba petunjuk sesuai dengan kebutuhan dan perkembangan zamannya. Masyarakat abad ke-6 menemukan budak-budak wanita, dan bagi merekalah tuntunan itu diberikan. Di sisi lain, kita tidak tahu perkmbangan masyarakat pada abad mendatang, boleh jadi mereka mengalami perkembangan yang belum dapat kita duga dewasa ini. Ayat-ayat ini atau jiwa petunjuknya dapat mereka jadikan rujukan dalam kehidupan mereka. ${ }^{20}$

Penafsiran yang terbaik menyangkut ayat di atas, adalah penafsiran yang berdasarkan keterangan istri Nabi saw., 'Aisyah ra. Imam Bukhari, Muslim, Abu Daud serta at-Tirmidzi dan lain-lain yang meriwayatkan bahwa Urwah Ibn Zubair bertanya kepad istri Nabi; 'Aisyah ra. Tentang ayat ini. Beliau menjawab bahwa ini berkaitan dengan anak yatim yang berada dalam

${ }^{18}$ Eka Prasetawati dan Habib Shulton Asnawi, "Wawasan Islam Nusantara; Pribumisasi Nilai-Nilai Kearifan Lokal di Indonesia," FIKRI: Jurnal Kajian Agama, Sosial dan Budaya 3, no. 1 (31 Juli 2018): 219, https://doi.org/10.25217/jf.v3i1.283.

${ }^{19}$ M. Quraish Shihab, Tafsir Al-Misbah Pesan, Kesan, dan Keserasian Al-Qur'an.

${ }^{20}$ M. Quraish Shihab. 
pemeliharaan seorang wali, dimana hartanya bergabung dengan harta wali, dan sang wali senang akan kecantikan dan harta sang yatim, maka dia hendak menikahinya tanpa memberinya mahar yang sesuai. Sayyidah 'Aisyah lebih lanjut menjelaskan bahwa setelah turunnya setelah ayat ini para sahabat bertanya lagi kepada Nabi saw. tentang perempuan, maka turunlah firman QS. AnNisā':127). 'Aisyah Kemudian melanjutnya keterangnnya bahwa firman-Nya: sedang kamu enggan menikahi mereka, bahwa itu adalah keengganan para wali untuk menikahi anak yatim yang sedikit harta dan kecantikannya. Maka sebaliknya dalam ayat 3 surah an-Nisa' ini, mereka dilarang menikahi anak-anak yatim yang mereka inginkan karena harta dan kecantikannya tetapi enggan berlaku adil terhadap mereka.

Penyebutan dua, tiga atau empat, pada hakikatnya adalah dalam rangka tuntutan berlaku adil kepada anak yatim. Redaksi ayat ini mirip dengan ucapan seorang yang melarang lain makan makanan tertentu, dan untuk menguatkan larangan ini dikatakannya: "jika anda khawatir akan sakit bila makan makanan ini, maka habiskan saja makanan selainnya yang ada di hadapan anda." Tentu saja perintah menghabiskan makanan lain itu, hanya skedar menekankan perlunya mengindahkan larangan untuk tidak makan makanan tertentu itu. Perlu digaris bawahi bahwa ayat ini, tidak membuat peraturan tentang poligami, karena poligami telah dikenal dan dilaksanakan oleh penganut berbagai syariat agama, serta adat istiadat masyarakat sebelum turunnya ayat ini. Sebagaimana ayat ini tidak mewajibkan poligami atau menganjurkannya, ia hanya berbicara tentang bolehnya poligami dan itu pun merupakan pintu kecil yang hanya dapat dilalui oleh yang sangat amat membutuhkan dan dengan syarat yang tidak ringan. Adalah wajar bagi satu perundangan, apalagi agama yang bersifat universal dan berlaku setiap waktu dan tempat untuk mempersiapkan ketetapan hukum yang boleh terjadi pada satu ketika.

Selanjutnya bukankah kemandulan, atau penyakit parah merupakan satu kemungkinan yang tidak aneh dan dapat terjadi di mana-mana? apakah jalan keluar yang dapat diusulkan kepada suami yang menghadapi kasus demikian? bagaimanakah seharusnya ia menyalurkan kebutuhan biologisnya? poligami ketika itu, adalah jalan keluar yang paling tepat. Namun sekali lagi perlu diingat bahwa ini bukan berarti anjuran, apalagi berarti kewajiban. Seandainya ia merupakan anjuran, pastilah Allah menciptakan wanita lebih banyak empat kali lipat dari jumlah lelaki. Ayat ini hanya memberi wadah bagi mereka yang menginginkannya, ketika menghadapi kondisi atau kasus tertentu, seperti yang dikemukakan contoh diatas. Tentu saja masih banyak kondisi atau kasus lain yang menjadi alasan logis untuk tidak menutup rapat pintu poligami yang dibenarkan oleh ayat ini dengan syarat yang tidak ringan itu. ${ }^{21}$

Kita tidak dapat membenarkan siapa yang berkata bahwa poligami adalah anjuran, dengan alasan bahwa perintah di atas dimulai dengan bilangan dua, tiga atau empat, baru kemudian kalau khawatir adil, maka nikahilah seorang saja, dengan alasan yang telah ditentukan di atas, baik dari makna redaksi ayat maupun dari segi kenyataan sosiologis di mana perbandingan perempuan dan laki-laki tidak mencapai empat banding satu, bahkan dua banding satu.

Tidak juga dapat dikatakan bahwa Rasul nikah lebih dari satu, dan pernikahan semacam itu hendaknya diteladani, karena tidak semua apa yang dilakukan Rasul perlu diteladani, sebagaimana tidak semua yang wajib atau terlarang bagi beliau, wajib dan terlarang pula bagimu. Apakah orang sekarang sungguh ingin meneladani Rasul dalam pernikahannya? kalau benar, maka perlu mereka sadari bahwa semua wanita yang beliau nikahi, kecuali 'Aisyah adalah janda dan bertujuan demi

\footnotetext{
${ }^{21}$ M. Quraish Shihab.
} 
menyukseskan dakwah, atau menyelamatkan para wanita yang kehilangan suami itu serta pada umumnya bukanlah wanita-wanita yang dikenal memiliki daya tarik yang memikat. Saudah binti Zam'ah, seorang wanita tua, suaminya meninggal di perantauan (Ethiopia) sehingga terpaksa kembali ke Mekkah menanggung beban kehidupan bersama anak-anak dengan resiko dipaksa murtad, atau nikah dengan siapa yang tidak disenanginya. ${ }^{22}$ Hind binti Abi Umayyah yang dikenal dengan Ummu Salamah, suaminya 'Abdullah al-Makhzumi yang juga anak pamannya mengalami luka dalam perang Uhud kemudian gugur, juga seorang tua sampai pada mulanya beliau menolak lamaran Rasul, sebagaimana beliau telah menolak sebelumnya lamaran Abu Bakar dan 'Umar, tetapi pada akhirnya bersedia demi kehormatan dan anak-anaknya. Ramlah, putri Abu Sufyan meninggalkan orang tuannya dan berhijrah ke Habasyah (Ethiopia) bersama suaminya, tetapi sang suami kemudian memilih agama Nasrani di sana dan menceraikannya, sehuingga dia hidup sendiri di perantauan, maka melalui Negus Pengusaha Ethiopia Nabi melamarnya, dengan harapan mengangkatnya dari penderitaan sekaligus menjalin hubungan dengan ayahnya yang ketika itu merupakan salah satu tokoh utama kaum musyrikin di Mekah.

Huriyah binti al-Haris adalah putri kepala suku dan termasuk salah seorang yang ditawan. Nabi menikahinya sambil memerdekannya, dengan harapan kaum muslimin dapat membebaskan para tawanan yang mereka tawan, dan hasilnya seperti yang diharapkan dan semua pada akhirnya memeluk islam. Huriyah sendiri memilih untuk menetap bersama Nabi Muhammad dan enggan kembali bersama ayahnya. Hafshah putri 'Umar Ibn al-Khaththab, suaminya meninggal, dan ayahnya merasa sedih ankanya hidup sendiri, maka dia "menawarkan" putrinya kepada Abu Bakar untuk dipersuntingnya, tetapi yang ditawari tidak menyambut, maka tawaran diajukan kepada 'Utsman beliau pun diam. Nah, ketika itu, 'Umar mengadukan kesedihannya kepada Nabi yang kemudian bersedia menikahi Hafshah demi persahabatan dan demi tidak membedakan 'Umar dengan sahabatnya Abu Bakar yang sebelum ini telah menikah putrinya yakni 'Aisyah. Zainab binti Jahsy, sepupu Nabi Muhammad saw, dinikahkan oleh Nabi dengan bekas anak angkat dan hamba sahaya beliau Zaid Ibn Haritsah. Rumah tangga mereka tidak bahagia, sehingga mereka bercerai, dan sebagai penanggung jawab pernikahan itu, Nabi Muhammad menikahinya atas perintah Tuhan, sekaligus untuk membatalkan adat Jahiliah, yang menggap anak angkat sebagai anak kandung, sehingga tidak boleh menikahi bekas istrinya (QS. Al-Aḥzāb [33]: 36-37). ${ }^{23}$ Itulah istri-istri Nabi Muhammad, yang keseluruhannya janda kecuali 'Aisyah dan yang beliau kawini setelah bermonogami hingga usia 50 tahun lebih, dan selama hidup bersama ibu putra putrinya Khadijah istri pertama dan tercinta beliau. Istri-istri yang disebut di atas inilah yang seringkali disoroti oleh mereka yang tidak mau memahami latar belakang pernikahan itu.

Ada yang bertanya mengapa Islam membenarkan pria menghimpun dalam saat yang sama empat orang wanita, sedang wanita tidak diperbolehkan kecuali dengan seorang pria? Boleh jadi ada yang tidak menerima pendapat ilmuan yang menyatakan bahwa fitrah pria cenderung berpoligami dan fitrah wanita bermonogami. Karena itu, Menjawab pertanyaan tersebut sebaiknya melihat kenyataan "mengapa negara-negara yang membolehkan prostitusi, melakukan pemeriksaan kesehatan rutin bagi wanita-wanita berprilaku seks bebas, dan tidak melakukannya bagi pasangan sah" ini karena kenyataan menunjukan bahwa wanita hanya diciptakan untuk disentuh oleh cairan yang bersih, yakni sperma seorang pria. Begitu terlibat dua pria dalam hubungan seksual dengan

\footnotetext{
${ }^{22}$ M. Quraish Shihab, Tafsir Al-Misbah Pesan, Kesan, dan Keserasian Al-Qur'an, hlm. 343.

${ }^{23}$ M. Quraish Shihab, Tafsir Al-Misbah Pesan, Kesan, dan Keserasian Al-Qur'an.
} 
seorang wanita, maka ketika itu pula cairan itu yang merupakan benih anak tidak bersih lagi dan sangat dikhawatirkan menjangkitkan penyakit. Kenyataan menjadi bukti yang menyangkut sangat jelas hal ini.

Firman-Nya: (ذلك أدنى ألاتعولوا) dipahami oleh Imam Syafi'i dalam arti tidak banyak tanggungan kamu. Terambil dari kata (عال-يعول) yang berarti menanggung/membelanjani. Orang memiliki banyak anak, berarti banyak tangannya. Dari ini kata itu dipahami dalam arti tidak banyak anak. Pemahaman kata itu demikian, tidak didukung oleh banyak ulama, tetapi hadits Nabi Saw. mendukung makna itu antara lain yang diriwayatkan Bukhari bahwa Nabi bersabda: "Tangan yang di atas (yang memberi) lebih baik dari pada tangan yang di bawah (menerima) dan mulailah dengan siapa yang menjadi tanggunganmu." Anda lihat Kata ( تعول) bermakna yang menjadi tanggungan. Jika pendapat itu diterima, maka ayat tersebut dapat dijadikan salah satu dasar untuk mengatur kelahiran dan menyesuaikan jumlah anak dengan kemampuan ekonomi. Memang sangat tercela bila kemampuan ruangan dan makanan yang tersedia hanya cukup untuk sepuluh orang, kemudian anda mengundang dua puluh orang. Demikian juga dengan anak-anak yang direncanakan. Buya Hamka dalam tafsirnya menjelaskan makna an-la ta'ulu artinya jangan sewenang-wenang supaya kalian tidak menanggung keluarga yang besar dan pula tidak boleh berat sebelah kepada salah seorang istri. Pendapat lain mengatakan al-la tamilu adalah tidak jatuh melarat. ${ }^{24}$ Menurut As-Syaukani an-la ta'ulu berarti memberatkan orang lain, melarat, payah tanggungan, sibuk, menjadi lemah sebab banyak tanggungan, payah mengangkat keluarga besar.

Pada ayat ini disebutkan bahwa pada dasarnya Islam tidak mewajibkan poligami atau menganjurkannya, akan tetapi, ia hanya berbicara tentang bolehnya berpoligami dan itupun merupakan jalan alternatif yang hanya dapat dilalui oleh orang-orang yang sangat membutuhkan dengan bersyarat. Itupun dengan diakhiri anjuran untuk bermonogami dengan Firman-Nya : "yang demikian itu adalah lebih dekat kepada tidak berbuat aniaya" ${ }^{25}$ Penafsiran poligami ditegaskan pula pada QS. Al-Nisā'/129:

"Dan kamu sekali-kali tidak akan dapat berlaku adil di antara isteri-isteri(mu), walaupun kamu sangat ingin berbuat demikian, karena itu janganlah kamu terlalu cenderung (kepada yang kamu cintai), sehingga kamu biarkan yang lain terkatung-katung. Dan jika kamu mengadakan perbaikan dan memelihara diri (dari kecurangan), maka sesungguhnya Allah Maha Pengampun lagi Maha Penyayang".

Setelah menganjurkan ihsan kepada pasangan atau berlaku adil, dijelaskannya di sini betapa keadilan harus ditegakkan, walaupun bukan keadilan mutlak apalagi dalam kasus poligami. Poligami sering kali menjadikan suami berlaku tidak adil, disisi lain kerelaan wanita untuk dimadu dapat juga merupakan bentuk perdamainaan demi memelihara pernikahan. Kepada suami semestinya berlaku adil, jika berpoligami. Melalui ayat ini para suami diberi semacam kelonggaran sehingga keadilan yang dituntut bukanlah keadilan mutlak. Ayat ini menegaskan bahwa para suami sekali-kali tidak akan dapat berlaku adil, yakni tidak dapat mewujudkan keadilan dalam hal cinta di antara para istri-mu walaupun kamu sangat ingin berbuat demikian, karena cinta di luar kemampuan

${ }^{24}$ Buya Hamka, Tafsir Al-Azhar diperkaya dengan pendekatan sejarah, sosiologi, tasawuf, ilmu kalam, sastra dan Psikologi, vol. 2 (Jakarta: Gema Insani, 2015).

25 Cak Syam, "POLIGAMI DAN KAWIN SIRRI MENURUT ISLAM," https://nambas.wordpress.com/2010/03/03/quraish-shihab-poligami-dan-kawin-sirri-menurut-islam/, 3 Maret 2010. 
manusia untuk mengaturnya. Karena itu, berlaku adil sekuat tenaga yakni dalam hal-hal yang bersifat material, dan kalaupun hatimu lebih mencintai dari salah seorang atas yang lain, maka sedapat mungkin janganlah kamu terlalu cenderung kepada istri yang kamu cintai sehingga kamu biarkan istrimu yang lain terkatung-katung tidak merasa diperhatikan sebagai istri dan tidak juga dicerai sehingga bebas untuk menikah atau melakukan apa yang dikehendakinya. Dan jika kamu setiap saat mengadakan perbaikan dengan menegakkan keadilan yang diperintahkan Allah dan bertakwa yakni menghindari aneka kecurangan serta memelihara diri dari segala dampak buruk, maka Allah akan mengampuni pelanggaran kecil yang kamu lakukan karena sesungguhnya Allah Maha Pengampun lagi Maha Penyayang.

Ayat ini sering dijadikan alasan oleh sebagian orang yang tidak mengerti bahwa Islam tidak merestui poligami, karena kalau izin berpoligami bersyarat dengan berlaku adil berdasarkan Firman-Nya Qs.an-Nisā [3]:4. Sedang disini dinyatakan bahwa, kamu sekali-kali tidak akan dapat berlaku adil di antara istri-istri kamu walaupun kamu sangat ingin berbuat demikian, maka hasilnya bahwa poligami tidak mungkin direstui. Pendapat ini, tidak dapat diterima, bukan saja karena Nabi dan banyak sahabat yang melakukan poligami, tetapi juga karena ayat ini tidak berhenti di tempat para penganut pendapat ini, tetapi berlanjut dengan menyatakan karena itu janganlah kamu terlalu cenderung (kepada yang kamu cintai). Penggalan ayat ini menunjukkan kebolehan poligami walau keadilan tidak dapat diwujudkan.

Seperti terbaca di atas, keadilan yang tidak dapat diwujudkan adalah dalam hal cinta. Bahkan cinta atau suka pun dapat dibagi. Suka yang lahir atas dorongan perasaan dan suka yang atas dorongan akal. Obat yang pahit, tidak disukai oleh siapa pun, ini berdasarkan perasaan setiap orang, tetapi obat yang sama, akan disukai karena akal si sakit mendorongnnya menyukai obat itu walau ia pahit. Demikian suka atau cinta dapat berbeda. Yang tidak mungkin diwujudkan adalah keadilan dalam hal cinta berdasarkan perasaan, sedang suka yang berdasarkan akal, dapat diusahakan manusia, yakni memperlakukan istri dengan baik, membiasakan diri dengan kekurangannya, memandang semua aspek yang ada padanya, bukan hanya aspek keburukannya. Inilah yang dimaksud dengan janganlah kamu terlalu cenderung (kepada yang kamu cintai) dan jangan juga terlalu cenderung mengabaikan yang kurang kamu cintai. Keadilan yang dimaksud ayat ini adalah keadilan di bidang imaterial (cinta). Itu sebabnya hati yang berpoligami dilarang memperturutkan hatinya dan berkelebihan dalam kecenderungan kepada yang dicintai. Dengan demikian tidaklah tepat menjadikan ayat ini sebagai dalih untuk menutup pintu poligami serapat-rapatnya. ${ }^{\mathbf{2 6}}$

\section{Analisis Konsep Poligami Menurut M. Quraish Shihāb dalam Tafsīr Al-Miṣbāḥ}

Konsep poligami dalam al-Qur'an, M. Quraish Shihab menekankan adanya keadilan dalam praktik poligami. Dimana keadilan dijadikan sebagai syarat utama yang wajib dipenuhi oleh seorang suami yang hendak melakuan poligami. Keadilan dalam poligami menurut beliau menyangkut beberapa aspek karena pada ayat 3 surat an-Nisā':4 masih berkaitan dengan ayat 2:

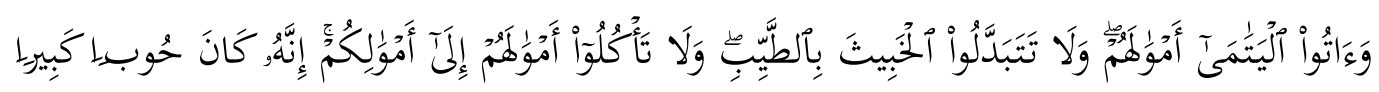

Dan berikanlah kepada anak-anak yatim (yang sudah balig) harta mereka, jangan kamu menukar yang baik dengan yang buruk dan jangan kamu makan harta mereka bersama

\footnotetext{
${ }^{26}$ M. Quraish Shihab, Wawasan Al-Qur'an, Tafsir Tematik Atas Pelbagai Persoalan Umat (Bandung: Mizan,
} t.t.). 
hartamu. Sesungguhnya tindakan-tindakan (menukar dan memakan) itu, adalah dosa yang besar. ${ }^{27}$

Ayat 2 ini mengingatkan kita akan keadilan mengelola harta anak yatim. Dengan poligami keadilan yang sering dipahami sebagai keadilan dalam memperlakukan para istri menjadi suatu persoalan yang dijawab oleh M. Quraish Shihab, dimana pemikiran ini dihasilkan dari metode maudú 'i dalam menafsirkan ayat-ayat al-Qur'an, diantaranya melakukan munasabah ayat-ayat sebelumnya dengan ayat yang sedang dikaji. Tafsir al-Ibriz menerangkan bahwa orang Islam di masa awal ketika ada yang merawat anak yatim dan kebetulan bukan mahrom maka kebanyakan dinikahi sekalian. Masa itu ada kejadian sampai beristri delapan atau sepuluh. Orang banyak yang khawatir tidak bisa berbuat adil dan gundah kemudian turunlah ayat ke-3 ketika seorang tidak mampu berbuat adil diantara anak yatim, maka boleh poligami 2 atau 3 atau 4 dari wanita yang disukai, tidak boleh lebih dari empat. ${ }^{28}$

Dalam konsep poligami keadilan merupakan hal yang sangat penting. Karena pada dasarnya keadilan bukan sekedar berbuat adil terhadap anak yatim melainkan keadilan poligami adalah bersifat material bukan non materi. M. Qurasih Shihab merujuk pada QS. An-Nisā’:4: 129 yakni:

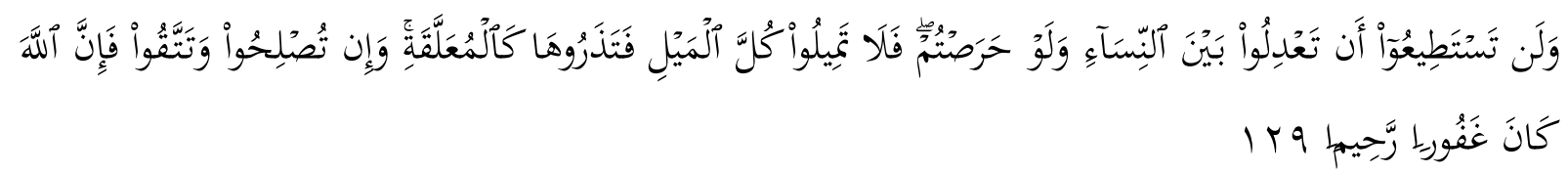

Dan kamu sekali-kali tidak akan dapat berlaku adil di antara isteri-isteri(mu), walaupun kamu sangat ingin berbuat demikian, karena itu janganlah kamu terlalu cenderung (kepada yang kamu cintai), sehingga kamu biarkan yang lain terkatung-katung. Dan jika kamu mengadakan perbaikan dan memelihara diri (dari kecurangan), maka sesungguhnya Allah Maha Pengampun lagi Maha Penyayang.

Keadilan pada ayat ini adalah keadilan di bidang imaterial (cinta dan kasih sayang ). ${ }^{\mathbf{2 9}}$ Disyaratkan pada ayat tersebut keadilan yang tidak bisa dicapai oleh kemampuan manusia, M. Quraish Shihab memahami keadilan dalam poligami hanya bidang imaterial (cinta dan kasih sayang). Kalaupun sulit diwujudkan disini adil dalam cinta dan kasih sayang, berbeda dengan suka yang berdasarkan akal yang masih bisa diusahakan oleh manusia, yaitu dengan memperlakukan istri dengan baik dan membiasakan diri dengan menerima kekurangnya. ${ }^{30}$ Menurut Kyai Musthofa Bisri keadilan yang dimaksud ialah hak istri mendapat materi (nafaqah) dan immaterial (nafkah batin/nggilir). Konsep adil dalam tafsir Maraghi dibatasi dengan memberikan sesuatu kepada istri sesuai dengan kemampuan suami semisal membeli rumah yang sama, pakaian, perhiasan dll. Adapun hal-hal di luar kemampuan manusia seperti kecenderungan hati terhadap seorang istri, suami tidak wajib berbuat adil sebagaimana Nabi Saw dikala masa tuanya lebih cenderung kepada Aisyah dibanding istri lainnya tetapi nabi tidak mengistimewakan sesuatu kecuali mendapat izin mereka. Adapun adil dalam tafsir al-Azhar meliputi hak atas suami dan hak tempat tinggal, nafkah sandang, pangan, nafkah batin dll.

M. Quraish Shihab mengatakan bahwa dalam tafsirannya beliau tidak mewajibkan poligami ataupun menganjurkannya, beliau hanya mengatakan tentang boleh dalam berpoligami, itu pun

${ }^{27}$ M. Quraish Shihab, Tafsir Al-Misbah Pesan, Kesan, dan Keserasian Al-Qur'an, 336.

${ }^{28}$ Bisri Musthofa, Al-Ibriz Terjemah Alquran Bahasa Jawa Latin, November 2015 (Kudus: Menara Kudus, 2015).

${ }^{29}$ M. Quraish Shihab, Wawasan Al-Qur'an, Tafsir Tematik Atas Pelbagai Persoalan Umat.

${ }^{30}$ M. Quraish Shihab, Tafsir Al-Misbah Pesan, Kesan, dan Keserasian Al-Qur'an. 
hanya sebagai pintu darurat kecil, dengan syarat yang tidak ringan ${ }^{31}$ Kalau tidak seperti itu bukan keindahan yang akan di dapat melainkan petaka dalam kehidupan. Dari uraian konsep poligami tersebut, beliau tidak mewajibkan suami untuk berpoligami, tetapi memperbolehkannya dengan memperlakukan istri secara adil. Senada dengan pendapat Shihab, Al-Maraghi juga membolehkan poligami dengan dengan ketat hanya untuk orang yang benar-benar membutuhkan semisal istri mandul, menopaus, tidak cukup dengan satu istri atau terjadi peperangan yang menyebabkan kaum pria banyak meninggal sehingga banyak janda yang tidak bisa menafkahi anak-anaknya maka demi kemaslahatan diperbolehkannya poligami. ${ }^{32}$

M. Quraish Shihab berpendapat tidak mewajibkan dan tidak pula menganjurkan bagi suami untuk berpoligami, akan tetapi memperbolehkannya. Dalam sini penulis mengambil contoh nyata ketika poligami dibolehkan dan menjadi positif dalam kehidupan. Tepatnya di daerah Bumi Ratu Nuban, Lampung Tengah mendapati seorang kepala rumah tangga yang melakukan poligami. Tepatnya bapak Ngadirun, beliau menjadi kepala rumah tangga dalam satu rumah dua isteri dan dikarunia 4 orang anak dari kedua istrinya, lebihnya uniknya kehidupan beliau tercukupi bahkan menjadi keluarga yang harmonis, rukun, guyub atau sakinah, mawadah wa rahmah. Dari contoh real di atas bahwa poligami tidak selalu serta merta menjadi hal buruk ketika tidak ada salah paham ataupun keterbukaan di antara dua pihak dan tidak adanya keterpaksaan dari kedua pihak.

M. Quraish Shihab menunjukan boleh berpoligami dengan syarat berat, disini penulis ingin menambahkan perspektif poligami dari kelompok yang berpendapat bahwa poligami dilarang secara mutlak. Sedangkan Hamka menyatakan boleh berpoligami tetapi berpikirlah keadilan dahulu sebelum terlanjur menempuh hal yang diperbolehkan syara'. Jangan pula karena hawa nafsu melihat perempuan yang disenangi saja. Musda Mulia sebagai feminis Indonesia mengkaitkan ayat ke 3 surat An-Nisā' dengan dua ayat sebelumnya. Ayat pertama berisi tentang perintah kepada manusia untuk bertakwa kepada Allah. Sedangkan ayat kedua berisi penegasan berlaku adil terhadap anak yatim. Secara spesifik ayat dua berbicara tentang anak yatim sebagai akibat dari terjadinya peperangan antar suku/ bangsa masyarakat Arab pada masa itu. Menjadi tradisi masyarakat jahiliah bahwa anak yang ditinggal mati orang tuanya di medan perang akan menjadi tanggung jawab dan kekuasaan para walinya. Termasuk dalam penguasaan harta-harta mereka sampai mereka dewasa dan mampu mengola hartanya sendiri

Kenyataanya yang terjadi berbeda, banyak para wali yang berperilaku curang terhadap anakanak yatim dengan tidak memberikan hartanya setelah dewasa dan para wali menukarkan barangbarang mereka yang baik dengan yang buruk atau mereka memakan harta anak yatim yang bercampur dengan harta mereka di dalamnya. Namapaknya tradisi seperti ini berlanjut hingga Islam datang dan ayat 3 dari surat an-Nisā' ini turun untuk mencegah perilaku para wali tersebut.

Dari turunnya ayat 3 surat an-Nisa', ini memberikan solusi dari permasalah itu, ayat ini turun di Madinah setelah kekalahan pasukan kaum muslimin di perang Uhud. Rasyid Ridha menambahkan asbāb an-nuzūl ayat ini adalah sebagaimana diriwayatkan oleh Imam Bukhāri, Muslim, Nasā'i dan Baihaqi dari Urwa Ibnu Zubair:” Dia bertanya kepada bibinya, Aisyah tentang sebab turunnya ayat ini. Lalu Aisyah menjelaskan bahwa ayat ini turun berkenaan dengan anak yatim yang berada dalam peliharaan walinya. Kemudian, walinya itu tertarik dengan kecantikan dan harta anak yatim itu dan mengawininya, tetapi tanpa mahar".

\footnotetext{
${ }^{31}$ M. Quraish Shihab, Wawasan Al-Qur'an, Tafsir Tematik Atas Pelbagai Persoalan Umat.

${ }^{32}$ Maraghi Mustafa, Tafsir Al-Maraghi, Terjemah, vol. 4 (Semarang: Toha Putra, 1993).
} 
Adanya riwayat tersebut menjadikan para penolak poligami tambah menghubungkan ayat 3 surat an-Nisa dengan an-Nisa ayat 129. Ayat ini menjelaskan tentang keadilan yang tidak mungkin dapat dipenuhi oleh suami yang berpoligami, meskipun mereka sangat ingin berbuat adil kepada isteri-isterinya. Menurut mereka adil yang disyaratkan adalah adil secara immateri (bathiniah) yang tidak akan dapat terpenuhi oleh suami yang berpoligami meskipun ia sangat ingin berlaku adil dan berusaha semaksiamal mungkin, sebagaimana disebutkan dalam ayat di atas "sesungguhnya kalian para suami tidak akan mampu berbuat adil di antara isteri-isterimu walaupun kalian sangat ingin berbuat demikian".

Nabi sekalipun tidak dapat berlaku adil. Sebagaimana diungkapkan oleh Aisyah bahwa Rasul mengadu kepada Allah perihal ketidak mampuannya dalam berlaku adil yang menyangkut keadilan cinta. Dengan dasar ayat inilah yang menjadi pembenaran dalam penolakan poligami, sebab keadilan yang menjadi syarat poligami tidak mungkin akan terpenuhi. Masyarakat Arab dahulu merupakan masyarakat kabilah yang menganut patriarki dimana kemegahan terletak pada banyaknya anak laki-laki dengan 10-15 istri dalam satu rumah. Sebab yang menjadi buah bibir di sana adalah jumlah anak dan cucu laki-laki, bahkan terbawa sampai sekarang kurang enak bila punya anak perempuan. Maka rasul tugasnya mengubah pandangan yang salah. Nabi memberi ketentuan bahwa anak perempuan pun berhak mendapat harta warisan dan istri dibatasi hanya 4 orang. ${ }^{33}$

Kenyataannya yang terjadi para pelaku poligami biasanya cenderung memperlakukan salah satu isterinya secara istimewa, dan mengabaikan hak-hak dari isteri lainnya. Apabila keadilan diukur dari perspektif isteri tentu dipastikan tidak mungkin suami dapat berlaku adil, dan selama ini ukuran keadilan hanya di dasarkan pada si suami, tidak di dasarkan pada isteri. Dengan turunya ayat ini” jika kamu takut tidak akan dapat berlaku adil, maka (nikahilah) seorang saja)" sudah seharusnya menjadi penghapusan poligami dengan adanya ayat tersebut.

Dari uraian di atas bagi kelompok yang menentang poligami dapat mengambil beberapa cacatan penting yaitu surat an-Nisa ayat 3 bukanlah sebagai dalil atau perintah, anjuran untuk melakukan poligami tetapi dalam konteks pembicaraan anak yatim yang kiranya para walinya dapat berlaku adil dan tidak semena-mena. Allah memperintahkan kepada para suami akan dua hal. Pertama, jangan menikahi anak yatim perempuan yang berada dalam kewalian mereka, kalau tidak mampu berlaku adil. Kedua, jangan berpoligami kalau tidak mampu berlaku adil. Faktanya, dalam dua hal tersebut manusia hampir-hampir mustahil dapat berlaku adil. Sehingga kesimpulan dari ayat tersebut adalah lebih berat mengandung ancaman berpoligami daripada membolehkannya karena praktek poligami sangat dimungkinkan menyakiti seseorang baik perempuan maupun keluarganya maka baiknya harus dihindari.

Adapun pisau analisis dari kaca mata yang kontra poligami seperti terjadi di daerah Karang Jati, Sampang, Cilacap, Jawa Tengah. Bapak Makin yang melakukan praktek poligami dengan dua orang isteri. Awal mula terjadinya poligami isteri pertama tidak mengetahui perihal tersebut akan tetapi seperti dalam pribahasa "sepandai-pandainya menyimpan bangkai pasti tercium juga". Pernikahan sirri yang dilakukan bapak makin tanpa seizin isteri pertama telah melukainya. Timbulnya keinginan untuk furqoh (cerai) sebagai isteri pertama yang merasa dikhianati muncul. Akan tetapi melihat ke belakang yang sudah di karunia 4 orang anak, sang isteri sedikit berfikir

${ }^{33}$ Hamka, Tafsir Al-Azhar diperkaya dengan pendekatan sejarah, sosiologi, tasawuf, ilmu kalam, sastra dan Psikologi. 
tentang kelangsungan masa depan anaknya hingga diurungkan niat cerai. Dari situ penulis gambarkan dari kelompok yang tidak setuju dengan adanya poligami yang terkadang menjadi salah dalam prakteknya dan menjadikan ketidakrealaan ataupun keterpaksaan dari seorang isteri yang di poligami dengan rasa sakit hati ketika dikhianati cintanya. Poligami akan berujung negatif bila prakteknya tidak adanya kerelaan dari pihak isteri yang selama ini banyak yang menganggap bahwa poligami akan baik-baik saja, ternyata setelah di lihat dari berbagai aspek poligami memiliki dampak psikologis pada istri, anak dan keluarga.

Dari uraian beberapa pendapat para ahli, penulis sampaikan bahwa kelompok yang setuju dengan poligami dan sebaliknya tentu memiliki argumen masing-masing dalam mempertahankan pendapatnya. Dalam konteks tempat dimana kita berada poligami akan selalu menjadi permasalahan yang unik, karena pada dasarnya poligami sudah ada sejak zaman dahulu dan termodifikasi dengan majunya zaman. Poligami bukan merupakan hukum yang wajib/sunnah untuk memiliki istri lebih dari satu, hanya membolehkan berpoligami dengan beberapa catatan ataupun syarat. Disisi lain, poligami bukanlah merupakan bukan jalan terbaik dalam penyelesaian masalah, karena sudah menjadi keharusan bagi orang tua untuk membimbing dan mendidik anaknya, dimana anak-anak tidak mendapat bimbingan dari orang tuanya akan menimbulkan kelemahan pada diri anak dalam perkembangan dan pertumbuhan psikologinya. Apabila hal yang diasumsikan diatas terjadi. Maka sudah dapat dibayangkan hubungan anak dan ayah pada masa mendatang.

Dari analisis penulis, bahwa dalam poligami tidak hanya mengedepankan emosi, egois seorang suami, melalaikan musyawarah dari suami dan istri dengan keterbukaan tanpa adanya masalah yang ditutupi dan keikhlasan dari seorang istri, walaupun istri sudah mengetahui konsep poligami yang sebenarnya, dengan hasil musyawarah dari kedua keluarga, tokoh agama dan masyarakat setempat akan memberikan solusi terbaik dalam masalah poligami agar tidak ada kesalahan dan tidak saling menyakiti satu sama lain. Dan terwujudnya makna pernikahan yang seutuhnya yakni sakinah mawadah warohmah.

\section{Kesimpulan dan Saran}

Dalam poligami M. Quraish Shihab tidak mewajibkannya ataupun menyarankannya, hanya mengatakan bolehnya dalam poligami. Dengan syarat adil yang tidak ringan. Itupun dijadikan pintu darurat yang sangat kecil. Makna keadilan menurut M. Quraish Shihab merupakan syarat poligami bukan pada keadilan immaterial (cinta dan kasih sayang) melainkan keadilan pada hal-hal yang

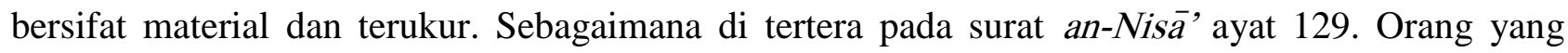
melaksanakan poligami adalah orang yang paham tentang ilmu-ilmu poligami dan tidak hanya karena menuruti nafsu belaka. Secara tidak langsung M. Qurasih Shihab memandang bahwa poligami tidak dapat dimunculkan untuk semua orang. Sebab kebolehan poligami merupakan pintu darurat bagi mereka yang berada dalam kondisi darurat. Orang yang melaksanakan poligami adalah orang yang memiliki jiwa dan misi kemanusiaan.

Poligami bukanlah hal yang mudah bahkan sangat sulit untuk memprakitkannya, bukan berarti tidak ada yang bisa berpoligami, hanya orang tertentu yang sanggup dan bisa melakukan poligami. Dari analisis yang dialakukan poin-poin yang dijadikan saran hendaknya masyarakat bersikap bijak dalam menyikapi masalah poligami sehingga tidak terjebak dengan kelompok yang pro dan kontra. Dalam wacana poligami harus mendapat perhatian dari seluruh komponen khuusnya tokoh agama sehingga masalah ini tidak lagi menjadi perdebatan yang terkadang masih memberikan 
kebingungan masyarakat. Pada akhirnya, penulis berharap, tulisan ini dapat berguna bagi para pembaca dan para pengkaji islam, khususnya dalam bidang tafsir

\section{Daftar Pustaka}

Agnia, Dina. "KAJIAN KRITIS BUDAYA PATRIARKHISME DALAM AGAMA DAN KEADILAN PEREMPUAN (STUDI KETENTUAN POLIGAMI DALAM UU. NO. 1 TAHUN 1974)." FIKRI : Jurnal Kajian Agama, Sosial dan Budaya Vol. 1, No. 1, (Juni 2016). http://journal.iaimnumetrolampung.ac.id/index.php/jf/article/view/283.

Cak Syam. "POLIGAMI DAN KAWIN SIRRI MENURUT ISLAM." Https://nambas.wordpress.com/2010/03/03/quraish-shihab-poligami-dan-kawin-sirrimenurut-islam/, 3 Maret 2010.

Cholid Narbuko Dan Abu Ahmadi. Metodologi Penelitian. Jakarta: Bumi Perkasa, 2009.

Didi Junaedi. "Mengenal Lebih Dekat Metode Maudhu'i” 04 Nomor 01 (Juni 2016).

Hamka, Buya. Tafsir Al-Azhar diperkaya dengan pendekatan sejarah, sosiologi, tasawuf, ilmu kalam, sastra dan Psikologi. Vol. 2. Jakarta: Gema Insani, 2015.

Hikmatulloh. "Konsep Poligami Dalam Islam (Studi Atas Penafsiran Sayyid Qutb), (Dalam Skripsi).” Sarjana Universitas Islam Negri Sunan Kalijaga Yogyakarta, 2002.

H.S.A Al Hamdani. Risalah Nikah (Hukum Perkawinan Islam). Jakarta: Pustaka Amani, 2002.

Imam Machali. "Poligami dalam perdebata teks dan konteks (melacak jejak argumentasi poligami dalam teks suci)" Volume 08, Nomer 01 (Juli 2015).

imam machaly. "Poligami dalam Perdebatan teks dan konteks: melacak jejak argumentasi poligami dalam teks suci" 08, Nomor 01 (2016).

M. Quraish Shihab. Tafsir al-misbah, pesan, kesan dan keserasian al qur'an. Vol. 2. Tanggerang: Lentera Hati, 2006.

- Tafsir Al-Misbah Pesan, Kesan, dan Keserasian Al-Qur'an. 02 vol. Jakarta: Lentera Hati, 2002.

-Wawasan Al-Qur'an, Tafsir Tematik Atas Pelbagai Persoalan Umat. Bandung: Mizan, t.t.

Makrum, Makrum. "POLIGAMI DALAM PERSPEKTIF AL-QUR'AN." MAGHZA 1, no. 2 (2016): 41-56.

Mustafa, Maraghi. Tafsir Al-Maraghi. Terjemah. Vol. 4. Semarang: Toha Putra, 1993.

Musthofa, Bisri. Al-Ibriz Terjemah Alquran Bahasa Jawa Latin. November 2015. Kudus: Menara Kudus, 2015.

Prasetawati, Eka, dan Habib Shulton Asnawi. "Wawasan Islam Nusantara; Pribumisasi Nilai-Nilai Kearifan Lokal di Indonesia." FIKRI : Jurnal Kajian Agama, Sosial dan Budaya 3, no. 1 (31 Juli 2018): 219. https://doi.org/10.25217/jf.v3i1.283.

Prasetiawati, Eka. "KONSEP PENDIDIKAN ANAK MENURUT AL-QUR'AN PERSPEKTIF MUHAMMAD QURAISH SHIHAB." TADBIR : Jurnal Manajemen Pendidikan Islam 5 No 1 (Februari 2017): 116.

. "Penafsiran Ayat-Ayat Keluarga Sakinah, Mawaddah, Wa Rahmah Dalam Tafsir AlMisbah Dan Ibnu Katsir." Nizham Journal of Islamic Studies 5, no. 2 (26 Desember 2017): 138-66.

Rochayah Machali. Wacana Poligami Di Indonesia. Bandung: Mizan, 2005.

Rosihan Anwar. Ilmu Tafsir. Bandung: CV Pustaka Setia, 2008.

Sugiyono. Metode Penelitian Pendidikan; Pendekatan Kuantitatif, Kualitatif dan R\&D. Bandung: Alfabeta, 2013.

Sukandarrumidi. Metodologi Penelitian. Yogyakarta: Gajah Mada University Press, 2004.

Sunaryo, Agus. "Poligami Di Indonesia (Sebuah Analisis Normatif-Sosiologis)." Yin Yang 5, no. 1 (2010): 143-167. 